\title{
SEARCHING FOR COMMON GROUND IN A LOCAL MEDIA CAMPAIGN
}

Frank Wallner

formerly of the National Heart Foundation

The NSW Health Department implements the ICAC guidelines on sponsorship. These guidelines must be considered before any partnership is formed with external organisations, and the appropriate approvals must be obtained. The NSW Health Department's Health Public Affairs Branch is able to provide advice on this process.

-his article describes how a local physical activity campaign, the National Heart Foundation Illawarra Physical Activity Project (located at the Mlawarra Health Promotion Unit), was able to build a valuable relationship with local businesses and expand the resources available for producing a mass media campaign.

\section{COMMUNICATING HEALTH MESSAGES TO THE PUBLIC}

Communicating health messages is an essential part of health promotion. Mass media alone may not be effective in changing health behaviour ${ }^{1,2}$ but mass media and social marketing strategies are well accepted as ways of creating community awareness of a health issue and setting the agenda to make behaviour change possible.

Few local health promotion projects have budgets which allow investment in awareness raising through paid placements in the media. This makes them reliant on unpaid publicity through community service announcements and press releases. One of the major strategic aims of the Illawarra Physical Activity Project has been to raise community awareness of the importance of moderate physical activity.

The project had a budget allocated to awareness raising through the media, but could not afford to produce a new campaign. For this reason, previous advertisements produced by interstate campaigns were reviewed, with the intention of producing new soundtracks and using the small media budget to buy air time. This approach was not pursued, primarily because the available advertisements were unsuitable for the population targeted by the project. In addition to the cost of producing new advertisements, the available media budget would have had to be at least doubled to cover the cost of paid media placements.

\section{SEEKING SHARED SOLUTIONS}

A local health fund and two television stations were approached to support a National Heart Foundation advertising campaign. While the television stations were willing to use our material as a community service announcement, they were not interested in offering more unless paid advertising was also purchased. The level of free support was clearly related to the size of advertising expenditure.

At a personal meeting, a representative of the health fund showed some interest in a collaborative media campaign. One of the television stations also expressed interest. A sponsorship proposal outlining our financial commitment and the expected campaign exposure was prepared and sent to the health fund. As the television station's support was unknown until we had a confirmed budget, it was impossible to provide the kind of specific information the health fund required to confirm its sponsorship. The health fund also sought publicity, and for this reason was heavily involved in the development of the content of the piece that was to go to air (the "creative").

\section{BALANCING ORGANISATIONAL NEEDS IN DEVELOPING THE ADVERTISEMENTS}

One of the major hurdles we faced was that, even if we were successful in obtaining the health fund's sponsorship, we would still have only a small budget to be stretched over a two-year period. We needed an advertising agency that was prepared to develop and produce the piece on a small and uncertain budget. As the first question any advertising agency asks is the size of the budget, we were an unappealing prospect for most agencies.

Tenders were called, and three small companies expressed some guarded interest. Two of the companies produced cartoons ("concept storyboards") which were market-tested with groups of blue-collar workers. The concept which elicited the most favourable responses was selected, and altered according to the test groups' comments. Feedback from the market testing, community surveys and focus groups indicated that the piece should:

\begin{tabular}{l|l} 
- be fun and not nag (using humour to promote \\
the message); \\
address some of the barriers to exercise; \\
convey the idea of accumulating moderate physical \\
activity; and \\
clearly explain the heart disease risk reduction \\
benefits of moderate activity.
\end{tabular}

All this had to be done in 20 seconds, as sponsor recognition advertising would fill the remaining 10 seconds.

The slogan for the campaign became "no ifs no buts". This slogan is now used in all promotional materials and publicity. The theme of the campaign was modelling walking behaviour for the whole family, while addressing typical excuses for not walking for exercise.

Representatives from the health fund and the television station were invited to all creative meetings, and had input into the final advertisement. They did not attend every meeting, but this open relationship was important in involving them as partners in the campaign rather than simply sponsors. After viewing the final storyboards and receiving a report on the market testing, the health fund agreed to fund the campaign on a dollar-for-dollar basis. Once this was confirmed, the television station agreed to provide a generous number of free advertising spots in addition to running the piece regularly as a community service announcement. From an initial $\$ 15,000$ total budget, the campaign now had a value of about $\$ 70,000$.

\section{'WHAT'S IN IT FOR US?'}

The health fund was interested in this media relationship for a number of reasons. It was seeking an association with the National Heart Foundation, which reflected an involvement with a community-based, preventive health project. The local flavour and the association with a positive, good-health message was important. The collaboration was also a productive business arrangement for the health fund, which received about three times the exposure it would have received by simply buying television time directly. 


\section{COUNCILS, COMMITMENT, OPPORTUNITY AND RELATIONSHIPS: HOW THEY COMBINE TO PROMOTE PHYSICAL ACTIVITY}

Margaret Thomas, Shauna Corne,

Jenni Humphries, Jeni Bindon

Central Sydney Health Promotion Unit

T his article describes a project to provide information to support members of a local community in increasing their level of physical activity. It provides an example of the need to work intersectorally to achieve health promotion goals ${ }^{1}$, a need which is particularly strong in the promotion of physical activity, where some aspects of the development of supportive environments are outside the scope of the health sector ${ }^{2}$.

In 1995 the Central Sydney Area Health Service Health Promotion Unit invited local interested parties (including representatives of local government, the local Division of General Practice, the National Heart Foundation and the local office of the Department of Sport and Recreation) to inaugurate a physical activity intersectoral working party. The Health Promotion Unit followed up the initial meeting by visiting each member of the working party to establish whether the most appropriate representative had attended the meeting and to investigate the core business of the group or organisation. At this stage we indicated our willingness to work on physical activity projects undertaken by the representatives' own organisations.

The members' enthusiasm and commitment to the working party has been maintained by establishing good informal relationships, and by working individually with members of the group to assist them with their own projects.

\section{THE DRUMMOYNE WALKING MAPS PROJECT}

One of the substantial projects undertaken by the working party was to develop maps promoting walking paths in the Drummoyne area. This project was carried out in partnership with Drummoyne Council. It was our good relationship with the council that enabled us to initiate this project, and our collaboration with the council's community services worker helped to foster the relationship.

The partnership with Drummoyne Council was strengthened by the fact that the maps would appear to the public as a council product.

Once we had established good working relationships, the success of the project rested on the commitment of the council to undertake its share of the work. A council worker mapped the distance of each walk, contributed to the design of the maps and drafted briefing notes for the mayor for the public launch. She also engaged her manager in the process so he was supportive of the project. His organisational position helped with crucial decisions, such as the council's decision to provide funding.

A local shopping centre sponsored the printing of the maps, provided a venue for the launch of the maps and helped to secure some local media coverage, in return for the use of its logo.

Working with Drummoyne Council on the walking maps project acted as a stimulus to promote local facilities and also helped to heighten the council's awareness of the importance of environments in the promotion of physical activity. Following the success of this project, we are working with a number of councils on a range of physical activity projects.

\section{CONCLUSIONS}

In our experience, the three key factors for successful intersectoral action are:

\begin{tabular}{l|l} 
- & $\begin{array}{l}\text { relationships } \\
\text { commitment } \\
\text { opportunity }\end{array}$
\end{tabular}

Working intersectorally has resulted in strong organisational relationships which will greatly enhance the promotion of physical activity in Central Sydney.

1. Harris E, Wise M, Hawe $P$, Finlay $P$, Nutbeam D. Working together: intersectoral action for health. Canberra: AGPS, 1995.

2. Bauman A, Bellew B, Booth M, Hahn A, Stoker L, Thomas M Towards best practice for the promotion of physical activity in the Areas of NSW. NSW Health Department, Centre for Disease Prevention and Health Promotion, 1996.

\section{A local media campaign}

- Continued from page 22

The local Illawarra television station also seeks opportunities for involvement in local community-based activities, as well as being interested in paid advertising.

\section{CONCLUSION}

It can be an advantage to operate at a local level in attempting to form collaborative relationships with the commercial sector. Many regional commercial organisations position themselves as local businesses, and for this reason seek associations with projects that are clearly communitybased. Associations with important, positive, "feel-good", preventive health campaigns reflect positively on the sponsoring organisation at the local level.

However, this in itself is not generally enough for businesses in competitive market environments. The fact that we had some money to put towards the campaign was extremely important, because it indicated the level and intent of our commitment. Since the Illawarra Physical Activity Project became a paying advertiser, the television station has been extremely helpful in covering other project stories, and is receptive to press releases from our project office. The value-added nature of the relationship was extremely important in ensuring it could be sustained.

Another advantage of working at a regional level is that it makes possible the development of personal relationships with commercial sector decision-makers. This is extremely important in helping to mesh health and commercial sector objectives, and allows far greater involvement by the commercial sector. Although the commercial media may not choose to be highly involved in a practical way, such a relationship greatly enhances the sense of being partners in a positive process.

1. Redman S, Spencer E, Sanson-Fisher R. The role of mass media in changing health-related behaviour: a critical appraisal of two models. Health Promotion International 1990; 5:85-100.

2. Owen N, Bauman A, Booth M, Oldenburg B, Magnus P. Serial mass media campaigns to promote physical activity: reinforcing or redundant? American Journal of Public Health 1995; 85:244-248. 